CLINICAL STUDY

\title{
Diagnostic interest of acid-labile subunit measurement in relationship to other components of the IGF system in pediatric patients with growth or eating disorders
}

\author{
V Barrios, J Argente, M T Muñoz, J Pozo, J A Chowen and M Hernández \\ Universidad Autónoma, Department of Pediatrics, Division of Pediatric Endocrinology, Laboratory of Research, Hospital Universitario Niño Jesús, \\ 28009 Madrid, Spain \\ (Correspondence should be addressed to J Argente, Division of Pediatric Endocrinology, Laboratory of Research, Hospital Niño Jesús, \\ Avda Menéndez Pelayo 65, 28009 Madrid, Spain; Email: argentefen@teleline.es)
}

\begin{abstract}
Objective: To analyze the possible utility of measuring acid-labile subunit (ALS) in some types of pathologies in which the IGF system is altered and to compare it with the clinical implications of measurements of other components of this axis.

Design and methods: We studied serum ALS concentrations in 20 children with normal variants of short stature (NVSS) at diagnosis and 24 with growth hormone deficiency (GHD), 18 obese patients and 18 girls with anorexia nervosa at diagnosis and during a follow-up period.

Results: In patients with GHD and anexoria nervosa, mean ALS concentrations were significantly reduced, but there was a high percentage of overlap with control values. At diagnosis, ALS concentrations were normal in obese patients and children with NVSS. During follow-up, these values normalized in children with GHD who were treated with GH, tended to normalize in those with anexoria nervosa who showed weight gain, and did not change in obese children upon weight loss. However, ALS measurement was less accurate than that of IGF-I or IGF binding protein (IGFBP)-3 in diagnosis of GHD. The correlations found between ALS and some IGF system components at diagnosis either decreased or were non-significant during follow-up of these clinical conditions.

Conclusion: ALS adds little information to that obtained with IGF-I and IGFBP-3 determinations.
\end{abstract}

European Journal of Endocrinology $144245-250$

\section{Introduction}

Various reports suggest the importance of acid-labile subunit (ALS) measurements in understanding the physiology and pathology of the insulin-like growth factor (IGF) system. The development of a simple enzyme-linked immunosorbent assay (ELISA) for the measurement of ALS (1) may now give us further insight into ALS physiology. Growth hormone (GH), which appears to be the main regulator of ALS, increases ALS gene transcription $(2,3)$, secretion of ALS by hepatocytes and serum concentrations of ALS. In contrast, these effects are not seen in response to IGF-I administration (4). Although there is little information available, ALS concentrations appear to be diminished in GH-deficient (GHD) patients (5), at least in adults suspected of being GHD (6), and increased in acromegalic patients (7); however, there is a high percentage of overlap with control values (1). In addition, ALS is subject to nutritional regulation, decreasing after fasting or caloric restriction. This effect could be mediated by changes in cyclic AMP concentrations (8). Furthermore, low ALS concentrations are seen in other catabolic conditions, such as insulin-dependent diabetes mellitus (9) or acute lymphoblastic leukemia (10). Hence, these data suggest that ALS may be implicated in both physiology and pathology and is potentially of clinical interest in order to assess possible abnormalities in the IGF axis (11).

Taking these findings into consideration, the purpose of this study was to analyze serum ALS concentrations in different pathologies in which the IGF system is altered and compare these results with those of normal individuals of the same age and pubertal stage (12), and to determine its usefulness as a marker in comparison with other components of this system.

\section{Study participants and methods}

\section{Study participants}

The study population included 24 children with isolated GHD, 20 with normal variants of short stature 
(NVSS), 18 girls with anorexia nervosa and 18 obese children. We also studies 60 healthy age-matched controls, divided into two groups according to their Tanner stage (13): I, 15 males and 15 females and V, 15 males and 15 females. The Tanner stages were evaluated according to breast development in girls and genital development in boys. Every control individual was referred to the Division of Endocrinology for suspected endocrine abnormalities and was found to be normal, with a height and weight between -1 and +1 S.D. according to Spanish standards (14).

GHD patients, with a height score of $-2.84 \pm 0.17$ S.D., were studied at diagnosis and after 3, 6, and 12 months of hGH therapy (0.6 IU/kg per week). All children with GHD presented a peak GH concentration less than $5 \mathrm{ng} / \mathrm{ml}$ in response to two provocative tests. Prepubertal children with NVSS had short stature $(-2.50 \pm 0.36$ S.D. $)$ and normal growth velocity $(-0.38 \pm 0.57$ s.D. $)$. Obese prepubertal individuals, with a mean body mass index (BMI) score of $3.66 \pm$ 1.19 S.D., were evaluated at diagnosis, after a $25 \%$ reduction in their BMI S.D. scores (corresponding to approximately 6 months after diagnosis), and at approximately 1 year after diagnosis, when a reduction of $50 \%$ or more from the initial s.D. score was obtained. Anorexic girls, with a mean BMI score of $-2.15 \pm$ 0.65 S.D., were studied at diagnosis, after recuperation of between $6-8 \%$ of their initial weight, at some time between 6 and 10 weeks after beginning treatment, and when $10 \%$ or more of the initial weight was recuperated (approximately 1 year after diagnosis). Blood samples of children and adolescents were withdrawn in fasted conditions between 0800 and $1000 \mathrm{~h}$.

Anthropometric parameters Height was measured in the morning by the same experienced staff using a wall stadiometer (Harpender Ltd). At all study points the weight was also measured and the BMI calculated and expressed as S.D. score. The S.D. scores were based upon normative data from Spanish children (14).

\section{Biochemical measurements}

Total ALS concentrations were determined by ELISA (DSL, Webster, TX, USA). Before the assay, the samples were pretreated to dissociate complexed ALS and to enhance dissociated and uncomplexed ALS immunoreactivity (1). The limit of sensitivity was $0.50 \mu \mathrm{g} / \mathrm{ml}$. The intra- and interassay coefficients of variation were $5.6 \%$ and $7.0 \%$ respectively.

Total IGF-I was performed, after acid-ethanol extraction, by RIA and IGF binding protein (IGFBP)-3 in non-extracted samples by the same method (Nichols, San Juan Capistrano, CA, USA). IGFBP-2 concentrations were evaluated by RIA (DSL). Free IGF-I (fIGF-I) was measured by IRMA and IGF-II was also determined, after acid-ethanol extraction, by IRMA (DSL).
Serum IGFBP-1 concentrations were determined by ELISA (Medix Biochemica, Kauniainen, Finland). The limits of sensitivity of these assays were $8.4 \mathrm{ng} / \mathrm{ml}$ for IGF-I, $0.06 \mathrm{ng} / \mathrm{ml}$ for fIGF-I, $16.5 \mathrm{ng} / \mathrm{ml}$ for IGF-II, $0.40 \mathrm{ng} / \mathrm{ml}$ for IGFBP- $1,0.62 \mathrm{ng} / \mathrm{ml}$ for IGFBP-2 and $0.06 \mu \mathrm{g} / \mathrm{ml}$ for IGFBP-3. Intra- and interassay coefficients of variation were $4.9 \%$ and $8.9 \%$ for IGF-I, $6.2 \%$ and $7.3 \%$ for fIGF-I, $5.2 \%$ and $8.7 \%$ for IGF-II, $4.6 \%$ and $9.8 \%$ for IGFBP- $1,5.7 \%$ and $7.2 \%$ for IGFBP- 2 and $3.6 \%$ and $6.1 \%$ for IGFBP-3 respectively.

\section{Statistics}

All results are expressed as the mean \pm S.D. All comparisons were made with age-matched controls. Sensitivity of the parameters analyzed was determined as the percentage of GHD children with a value less than -2 S.D. Specificity in patients with a normal GH response was defined as the percentage with a value greater than -2 S.D. Test accuracy was calculated as the number of GHD children with low values plus patients with NVSS who had a normal value, divided by all patients. Differences between the groups were determined by performing a one-way analysis of variance (ANOVA), followed by Scheffé's F test. Significance was chosen as $P<0.05$. Correlations between ALS and the components of the IGF system studied were analyzed using linear regression analyses.

\section{Results}

\section{Serum ALS concentrations}

Mean ALS concentrations were significantly lower (ANOVA: $P<0.05$ ) in patients with GHD (Fig. 1A) and anorexia nervosa (Fig. 1C) at diagnosis compared with age-matched controls. Mean values were normal in children with NVSS (Fig. 1B) and in obese children at all study periods (Fig. 1D). After 3 months of GH replacement in the GHD group, ALS concentrations returned to control values and remained stable throughout the rest of the study period (Fig. 1A). However, ALS values remained significantly reduced $(P<0.05)$ in patients with anorexia nervosa (Fig. 1C), in spite of weight recuperation.

\section{Serum IGF-I, IGF-II, IGFBP-1 and -3 concentrations}

Mean ( \pm S.D.) serum concentrations of these components of the peripheral IGF axis are presented in Table 1. GHD patients showed significantly greater concentrations of IGFBP-1 and lower concentrations of IGFBP-3 (ANOVA: $P<0.05$ ) than control children and both parameters returned to control values after 3 months of GH replacement. However, IGF-I was significantly diminished at diagnosis $(P<0.05)$ and, in spite of increasing after treatment, remained lower than 

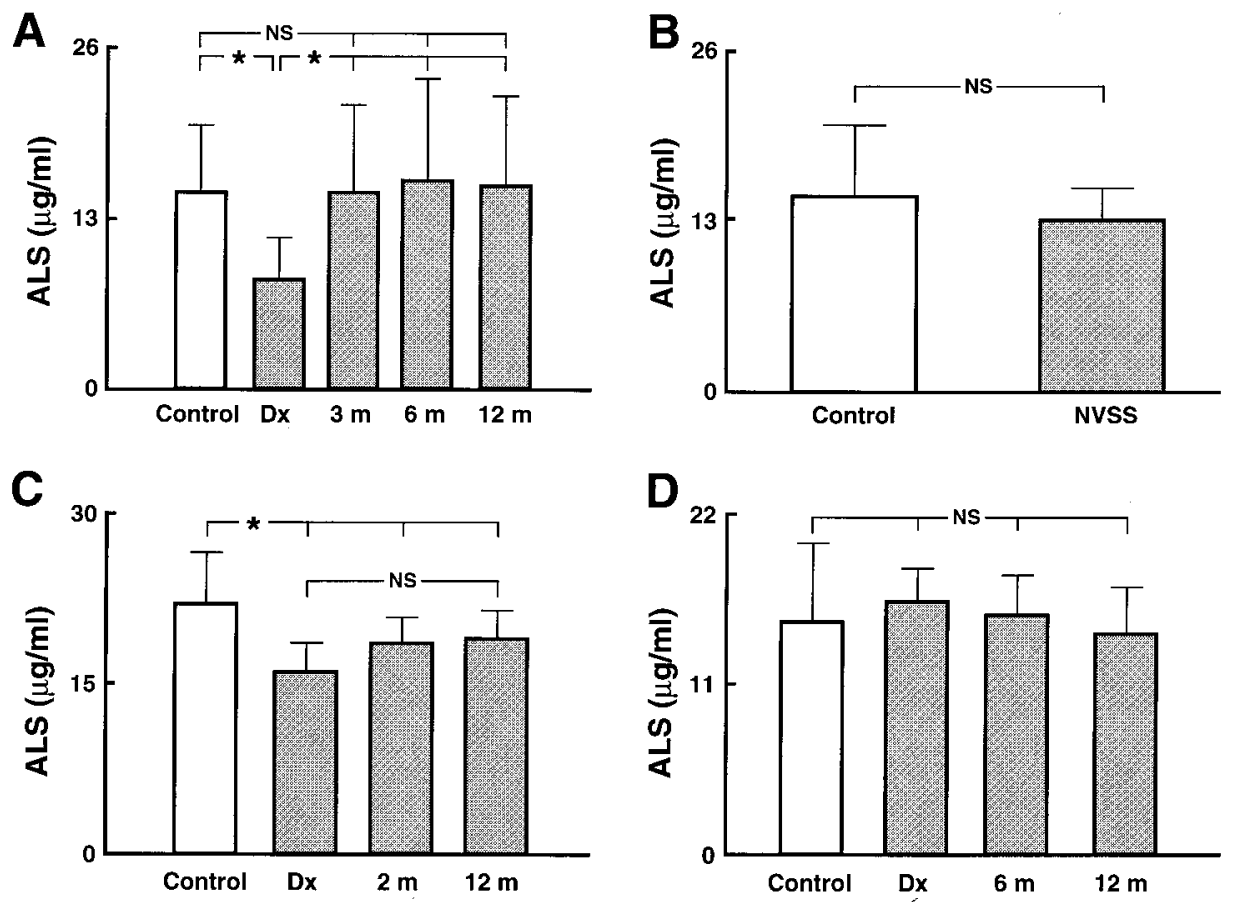

Figure 1 Concentrations of ALS in sera of control individuals and in patients with GHD (A), NVSS (B), anorexia nervosa (C) and exogenous obesity (D), at diagnosis (Dx) and 3, 6 and 12 months $(m)$ later. For details see Methods and Results. ${ }^{*} P<0.05$, by ANOVA.

control values. Children with NVSS presented normal values of these parameters. Anorexic patients had significantly reduced IGF-I and IGFBP-3 and increased IGFBP-1 concentrations $(P<0.05)$ and these values did not normalize even after recuperation of more than $10 \%$ of body weight. IGF-II concentrations were normal at diagnosis and increased at the end of the study $(P<0.05)$. In obese children, IGF-I concentrations were in the normal range at every study point and IGFII concentrations were significantly elevated at all times $(P<0.05)$. IGFBP-1 was low both before and after weight reduction. Serum IGFBP-3 concentrations were

Table 1 Mean \pm S.D. serum IGF-I, IGF-II, IGFBP-1 and IGFBP-3 concentrations in individuals with GHD, NVSS, anorexia nervosa and exogenous obesity (for details see Methods).

\begin{tabular}{|c|c|c|c|c|}
\hline & Diagnosis & Follow-up 1 & Follow-up 2 & Follow-up 3 \\
\hline \multicolumn{5}{|l|}{ GHD } \\
\hline IGF-I (ng/ml) & $95 \pm 42^{*}$ & $201 \pm 83^{*}$ & $198 \pm 60^{*}$ & $217 \pm 44^{*}$ \\
\hline IGF-II (ng/ml) & NA & NA & NA & NA \\
\hline IGFBP-1 (ng/ml) & $27.3 \pm 12.4$ & $12.6 \pm 8.0$ & $10.7 \pm 7.9$ & $11.0 \pm 8.5$ \\
\hline IGFBP-3 $(\mu \mathrm{g} / \mathrm{ml})$ & $1.9 \pm 0.4^{\star}$ & $2.9 \pm 0.7$ & $3.0 \pm 0.6$ & $2.9 \pm 0.8$ \\
\hline \multicolumn{5}{|l|}{ NVSS } \\
\hline IGF-I (ng/ml) & $233 \pm 65$ & & & \\
\hline IGF-II (ng/ml) & NA & & & \\
\hline IGFBP-1 (ng/ml) & $12.7 \pm 6.8$ & & & \\
\hline IGFBP-3 $(\mu \mathrm{g} / \mathrm{ml})$ & $2.9 \pm 0.5$ & & & \\
\hline \multicolumn{5}{|l|}{ Anorexia nervosa } \\
\hline IGF-I (ng/ml) & $337 \pm 131^{*}$ & $382 \pm 143^{*}$ & $390 \pm 126^{*}$ & \\
\hline IGF-II (ng/ml) & $624 \pm 111$ & $646 \pm 101$ & $712 \pm 127^{*}$ & \\
\hline IGFBP-1 (ng/ml) & $4.4 \pm 2.7^{*}$ & $3.8 \pm 1.4^{*}$ & $4.0 \pm 2.1^{*}$ & \\
\hline IGFBP-3 $(\mu \mathrm{g} / \mathrm{ml})$ & $3.2 \pm 0.8^{*}$ & $3.5 \pm 0.6^{\star}$ & $3.6 \pm 0.4^{*}$ & \\
\hline \multicolumn{5}{|l|}{ Exogenous obesity } \\
\hline IGF-I (ng/ml) & $287 \pm 74^{*}$ & $334 \pm 101$ & $273 \pm 81$ & \\
\hline IGF-II (ng/ml) & $671 \pm 163^{*}$ & $568 \pm 137^{*}$ & $658 \pm 125^{*}$ & \\
\hline IGFBP-1 (ng/ml) & $5.1 \pm 2.8^{\star}$ & $5.2 \pm 2.7^{\star}$ & $5.3 \pm 3.9^{\star}$ & \\
\hline IGFBP-3 ( $\mu \mathrm{g} / \mathrm{ml})$ & $3.9 \pm 0.4^{*}$ & $3.5 \pm 0.6$ & $3.4 \pm 0.7$ & \\
\hline
\end{tabular}

$\mathrm{NA}$, not available.

${ }^{*} P<0.005$ compared with control group 
Table 2 Linear correlations between ALS and IGF-I, fIGF-I, IGF-II, IGFBPS-1-3 in control individuals (Tanner stages I (TI) and V (TV)), GHD, NVSS, anorexia nervosa (AN) and exogenous obesity (EOB) (for details see Methods).

\begin{tabular}{|c|c|c|c|c|c|c|c|c|c|}
\hline & \multicolumn{2}{|c|}{ Controls } & \multicolumn{4}{|c|}{ Diagnosis } & \multicolumn{3}{|c|}{ Follow-up } \\
\hline & $\mathrm{TI}$ & TV & GHD & AN & OB & NVSS & GHD & AN & EOB \\
\hline & 0.46 & 0.73 & & NS & & & 0.59 & NS & NS \\
\hline & & & & NS & 0.49 & & NA & NS & NS \\
\hline & $\mathrm{N}$ & NS & NA & 0.60 & $\mathrm{~N}$ & & NA & NS & NS \\
\hline IGFBP-1 & NS & NS & -0.63 & NS & NS & -0.49 & -0.48 & NS & NS \\
\hline IGFBP-2 & NS & NS & NS & -0.55 & NS & NS & NS & NS & NS \\
\hline IGFBP-3 & 0.57 & 0.70 & 0.83 & NS & 0.72 & 0.74 & 0.56 & NS & 0.54 \\
\hline
\end{tabular}

NS, not significant; NA, not available.

increased at diagnosis $(P<0.05)$ and returned to control values after a $50 \%$ reduction of the BMI s.D. score.

\section{Regression analyses}

The results of all regression analyses performed with the biochemical parameters studied are presented in Table 2. A non-significant correlation was detected between ALS and BMI (not shown). A positive correlation between ALS concentrations and IGF-I and IGFBP-3 and a negative correlation with IGFBP-1 was found at diagnosis in GHD and NVSS children. A weak positive relationship was found between ALS and fIGF-I in obese children and a significant inverse relationship was found between ALS and IGFBP-2 in anorexic girls at diagnosis. All correlations declined or became non-significant during the evaluation of these patients.

\section{ALS sensitivity and specificity}

Serum ALS concentrations were less than -2 s.D. in 16 of the 24 patients with GHD and more than -2 S.D. in 14 of the 20 children with NVSS (Fig. 2). In contrast to ALS, IGF-I and IGFBP-3 values were less than -2 s.D. in 21 and 20 respectively of the 24 children with GHD and greater than -2 S.D. in 13 and 15 respectively of the patients with NVSS. Two GHD patients with normal or borderline IGFBP-3 concentrations presented low ALS concentrations and one child in the same group had normal IGF-I and low ALS concentrations. Sensitivities and specificities for ALS, IGF-I, IGFBP-2, ratio of IGFBP-2/IGF-I and IGFBP-3 are given in Table 3.

\section{Discussion}

In the present study we measured serum ALS concentrations in pediatric patients with GHD, NVSS and obesity, and in anorexic adolescents. The relationship between ALS and other parameters of the IGF system was also investigated. Finally, we analyzed the
Table 3 Diagnostic value of ALS, IGF-I, IGFBP-2, IGFBP-2/IGF-I ratio and IGFBP-3 concentrations in 24 GHD patients and 20 NVSS children with a normal GH secretion. For details see Methods and Results.

\begin{tabular}{lccc}
\hline & Sensitivity (\%) & Specificity (\%) & $\begin{array}{c}\text { Test } \\
\text { accuracy (\%) }\end{array}$ \\
\hline ALS & 66.7 & 70.0 & 68.2 \\
IGF-I & 87.5 & 65.0 & 77.3 \\
IGFBP-2 & 62.5 & 60.0 & 61.4 \\
IGFBP-2/IGF-I & 83.3 & 65.0 & 74.5 \\
IGFBP-3 & 83.3 & 75.0 & 79.5 \\
\hline
\end{tabular}

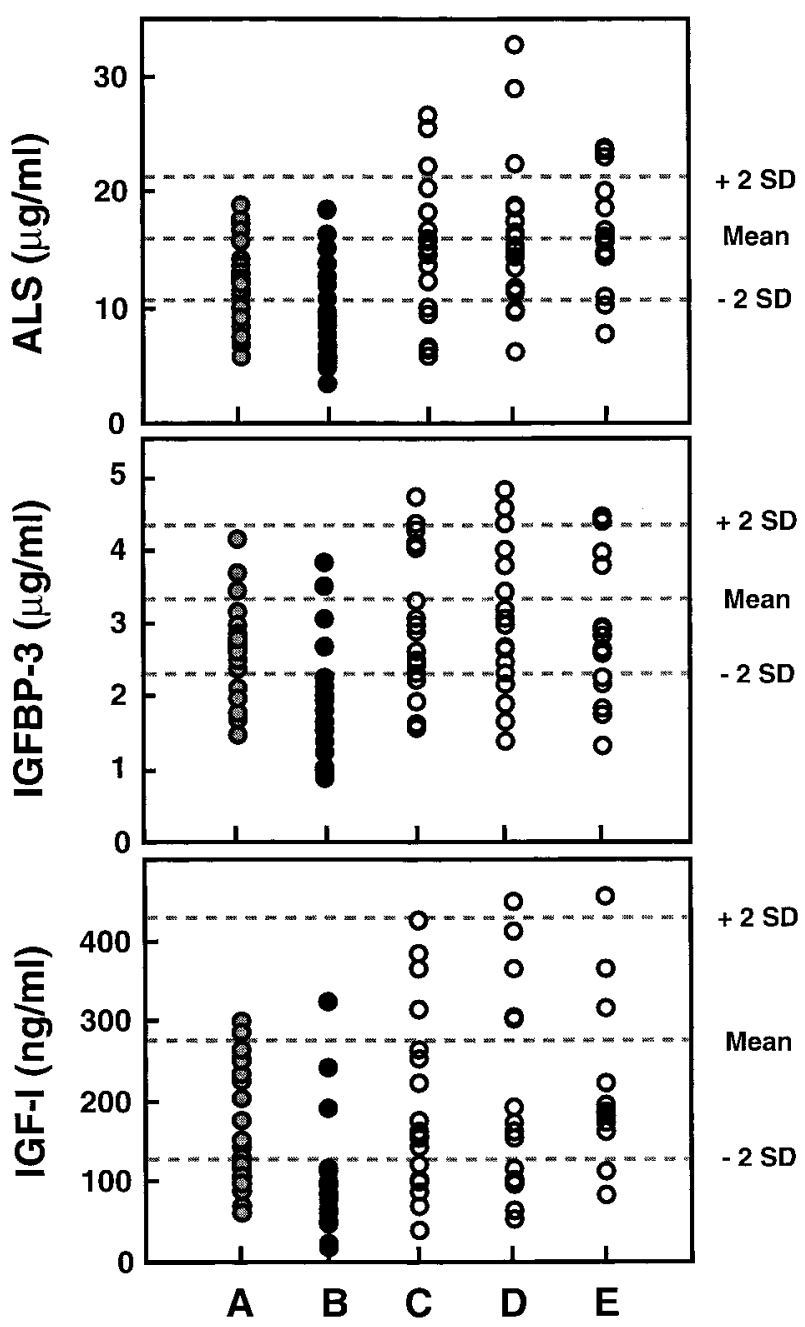

Figure 2 Serum concentrations of ALS, IGFBP-3 and IGF-I in children with NVSS at diagnosis (A) and GHD pediatric patients at diagnosis (B) and followed after $3(\mathrm{C}), 6$ (D) and 12 months (E) of $\mathrm{GH}$ replacement. Mean \pm 2 s.D. values were obtained from data of 30 age-matched control children for ALS and 252 age- and sexmatched children for IGFBP-3 and IGF-I. 
diagnostic value of ALS as compared with other components of this system.

Serum ALS concentrations were decreased in GHD children and normalized after GH replacement. Low ALS concentrations in GHD patients have been reported previously $(1,5,6)$. The patients with short stature and normal GH secretion included in this study had normal serum ALS concentrations; it is also known that GH therapy in patients with GH insensitivity does not change serum ALS concentrations (15). These findings suggest that GH is the main regulator of ALS and that the action of IGF-I on this glycoprotein is exerted by supressing GH secretion (16).

When we analyzed the possible diagnostic value of ALS in GHD patients, we found an accuracy of $68.2 \%$. This is similar to the value reported by Juul et al. (5). This value could be considered low if compared with the accuracy obtained with IGF-I or IGFBP-3. However, it may be premature to exclude ALS as a possible complementary diagnostic tool. Further studies of this parameter must be performed in conjunction with other members of this system, especially IGF-I and IGFBP-3, in order to determine how the greatest accuracy at diagnosis may be achieved.

Our data show low serum ALS concentrations at diagnosis and a partial increase in these concentrations after weight recuperation in anorexic girls, but have a greater overlap with control values than IGF-I or IGFBP-3 (17). These diminished ALS concentrations could be explained, at least in part, by the hypoinsulinemic state of these patients, as insulin therapy has been reported to restore ALS concentrations in other catabolic situations (9). We did not find a correlation between ALS concentrations and BMI. This result differs from that of the study by Fukuda et al. (18), who described a weak relationship between these parameters. This could be due to the low number of patients included in this study.

Patients with anorexia nervosa may present a partial $\mathrm{GH}$ resistance, as suggested by their reduced GHBP concentrations (17), although the interrelationship between GHBP and GH receptors is now being reexamined in some pathologies (19). Reduced GHBP concentrations may represent a down-regulation of the number of GH cell-surface receptors as a result of the undernutrition, and hence a decreased GH sensitivity that leads to reduced ALS synthesis. As with ALS, nutritional status and dietary changes also affect other components of the IGF system, especially IGF-I and IGFBP-3 $(20,21)$ which, along with ALS, form the ternary complex. However, IGF-I and IGFBP-3 show greater increases than ALS after dietary manipulations (22) and are most probably better markers in assessment of nutritional status. Although ALS does not seem to be an excellent indicator of the nutritional status, its measurement in parallel with that of other members of the IGF system could increase the information on the status of these patients.
Obese children presented normal serum ALS concentrations that remained stable in spite of weight reduction. In fact, our study shows an absence of correlation between ALS and body mass index. These patients have disturbances in the IGF system, such as decreased GH secretion and increased serum GHBP concentrations, high free IGF-I and hyperinsulinemia $(23,24)$ - factors that could regulate ALS synthesis or liberation differentially. Because of the multiplicity of factors implicated in the regulation of this glycoprotein, it is difficult to understand its modulation in this situation. However, it is possible that these normal ALS concentrations are the result of an integration of the low GH and high GHBP concentrations. In spite of their low GH levels, obese patients present high GHBP levels (25) and this may indicate an increased number of GH receptors in peripheral tissues, including liver (26), where they are coexpressed with ALS (27). Data on alterations in ALS in undernutrition have been reported (28), but less is known about overnutrition. However, it appears that ALS is a less sensitive marker than other components of the peripheral IGF axis in assessing problems of obesity.

The correlation between ALS and IGF-I or IGFBP-3 in GHD and NVSS patients at diagnosis declined during GH replacement. In obese children a similar loss of correlation occurred between ALS and IGF-I; in anorexic girls there was a loss of correlation between ALS and IGF-II and IGFBP-2 during weight reduction or recuperation respectively. The reason is not clear, but it could be an imbalance between the different IGF system peptides during the normalization period.

In conclusion, ALS does not add to the clinical assessment of these patients beyond the information gained from IGF-I plus IGFBP-3 measurements.

\section{Acknowledgements}

This work was supported by the Fundación Endocrinología y Nutrición and Comunidad Autónoma de Madrid (08.5/0009/1997).

\section{References}

1 Khosravi MJ, Diamandi A, Mistry J, Krishna RG \& Khare A. Acidlabile subunit of human insulin-like growth factor-binding protein complex: measurement, molecular, and clinical evaluation. Journal of Clinical Endocrinology and Metabolism 199782 3944-3951.

2 Ooi GT, Cohen FJ, Tseng LYH, Rechler MM \& Boisclair YR. Growth hormone stimulates transcription of the gene encoding the acid-labile subunit (ALS) of the circulating insulin-like growth factor-binding protein complex and ALS promoter activity in rat liver. Molecular Endocrinology 199711 997-1007.

3 Rhoads RP, Greenwood PL, Bell AW \& Boisclair YR. Organization and regulation of the gene encoding the sheep acid-labile subunit of the 150-kilodalton insulin-like growth factor-binding protein complex. Endocrinology 2000141 1425-1433.

4 Labarta JI, Gargosky SE, Simpson DM, Lee PDK, Argente J, Guevara-Aguirre J \& Rosenfeld RG. Growth hormone, but not 
insulin-like growth factor (IGF)-I, regulates the acid-labile subunit of the IGF binding protein (IGFBP)-3. Clinical Endocrinology 199747 657-666.

5 Juul A, Møller S, Mosfeldl-Laursen E, Rasmussen MH, Scheike T, Pedersen SA et al. The acid-labile subunit of human ternary insulin-like growth factor binding protein complex in serum: hepatosplanchnic release, diurnal variation, circulating concentrations in healthy subjects, and diagnostic use in patients with growth hormone deficiency. Journal of Clinical Endocrinology and Metabolism $1998 \mathbf{8 3} 4408-4415$.

6 Thorén M, Hilding A, Baxter RC, Degerblad M, Wivall-Helleryd IL \& Hall K. Serum insulin-like growth factor I (IGF-I), IGF-binding protein-1 and -3, and the acid-labile subunit as serum markers of body composition during growth hormone $(\mathrm{GH})$ therapy in adults with GH deficiency. Journal of Clinical Endocrinology and Metabolism 199782 223-228.

7 Hoffman D, Baxter R, O'Sullivan A, Crampton L \& Ho K. Serum acid-labile subunit in adult growth hormone deficiency and acromegaly. Endocrinology and Metabolism 1997423 (Abstract).

8 Delhanty PJ \& Baxter RC. The regulation of acid-labile subunit gene expression and secretion by cyclic adenosine 3', 5'monophosphate. Endocrinology 1998139 260-265.

9 Bereket A, Lang $\mathrm{CH} \&$ Wilson TA. Alterations in the growth hormone-insulin-like growth factor axis in insulin dependent diabetes mellitus. Hormone and Metabolic Research 199931 172181.

10 Argüelles B, Barrios V, Pozo J, Madero L \& Argente L. Longitudinal study of the ternary complex of human insulin-like growth factors (IGFs) in children with acute lymphoblastic leukemia (ALL). Hormone Research 19985030 (Abstract).

11 Baxter RC. The binding protein's binding protein. Clinical applications of acid-labile subunit (ALS) measurement. Journal of Clinical Endocrinology and Metabolism 199782 3941-3943.

12 Barrios V, Pozo J, Muñoz MT, Buño M \& Argente J. Normative data for total and free acid-labile subunit (ALS) of the human insulin-like growth factor-binding protein complex in pre- and full-term newborns and healthy boys and girls throughout postnatal development. Hormone Research 200053 148-153.

13 Tanner JM.In Growth and Adolescence, edn. 2. Oxford: Blackwell Scientific Publications, 1962.

14 Hernández M, Castellet J, Narvaíza JL, Rincón JM, Ruiz I, Sánchez E et al. Curvas y Tablas de Crecimiento. Eds M Hernández and Fundación F. Orbegozo. Madrid: Editorial Garsi, 1988.

15 Burren CP, Wanek D, Mohan S, Cohen P, Guevara-Aguirre J \& Rosenfeld RG. Serum levels of insulin-like growth factor binding proteins in Ecuadorean children with growth hormone insensitivity. Acta Paediatrica 199988 185-191.

16 Kupfer SR, Underwood LE, Baxter RC \& Clemmons DR. Enhancement of the anabolic effects of growth hormone and insulin-like growth factor I by use of both agents simultaneously. Journal of Clinical Investigation 199391 391-396.

17 Argente J, Caballo N, Barrios V, Muñoz MT, Pozo J, Chowen JA et al. Multiple endocrine abnormalities of the growth hormone and insulin-like growth factor axis in patients with anorexia nervosa: effect of short and long-term weight recuperation. Journal of Clinical Endocrinology and Metabolism 1997822084 2092.

18 Fukuda I, Hotta M, Hizuka N, Takano K, Ishikawa Y, AsakawaYasumoto K et al. Decreased serum levels of acid-labile subunit in patients with anorexia nervosa. Journal of Clinical Endocrinology and Metabolism 199984 2034-2036.

19 Amit T, Youdim MBH \& Hochberg Z. Does serum growth hormone $(\mathrm{GH})$ binding protein reflect human $\mathrm{GH}$ receptor function? Journal of Clinical Endocrinology and Metabolism 2000 85 927-932.

20 Counts DR, Gwirtsman H, Carlsson LM, Lesem M \& Cutler GB Jr. The effect of anorexia nervosa and refeeding on growth hormone-binding protein, the insulin-like growth factors (IGFs), and the IGF-binding protein. Journal of Clinical Endocrinology and Metabolism $199275762-767$.

21 Smith WJ, Underwood LE \& Clemmons DR. Effects of caloric or protein restriction on insulin-like growth factor-I (IGF-I) and IGF binding protein in children and adults. Journal of Clinical Endocrinology and Metabolism 199580 443-449.

22 Donahue SP \& Phillips LS. Response of IGF-I to nutritional support in malnourished hospital patients: a possible indicator of short-term changes in nutritional status. American Journal of Clinical Nutrition 198950 962-969.

23 Frystyk J, Vestbo E, Skjaerbaek C, Mogensen CE \& Ørskov H. Free insulin-like growth factors in human obesity. Metabolism 1995 44 37-44.

24 Zannoli R, Rebeggiani A, Chiarelli F \& Morgese G. Hyperinsulinism as a marker in obese children. American Journal of Disease Children 1993147 837-841.

25 Argente J, Caballo N, Barrios V, Pozo J, Muñoz MT, Chowen JA et al. Multiple endocrine abnormalities of the growth hormone and insulin-like growth factor axis in prepubertal children with exogenous obesity: effect of short and long-term weight reduction. Journal of Clinical Endocrinology and Metabolism 1997 82 2076-2083.

26 Leung DW, Spencer SA, Cachianes G, Hammonds RG, Collins C, Henzel WJ et al. Growth hormone receptor and serum binding protein: purification, cloning and expression. Nature 1987330 $537-543$.

27 Chin E, Zhou J, Dai J, Baxter RC \& Bondy CA. Cellular localization and regulation of gene expression for components of the insulinlike growth factor ternary binding protein complex. Endocrinology $19941342498-2504$.

28 Donaghy AJ, Baxter RC, Insulin-like growth factor bioactivity and its modification in growth hormone resistant states. Bailliere's Clinical Endocrinology and Metabolism 199610 421446.

Received 24 July 2000

Accepted 13 November 2000 